\title{
ANAL YSING THE IMPACT OF ECONOMIC POLICIES ON UNEMPLOYMENT AND POVERTY IN NIGERIA
}

\author{
FELIX CHINEDU OMENE \\ Department of Economics, University of Abuja. \\ felixjason88@gmail.com, 08062918218
}

\begin{abstract}
This study is carried out to empirically examine the effect of economic policies on unemployment and poverty in Nigeria between 1970-2019. The persistent and high level of poverty in Nigeria accompanied by severe unemployment despite the adoption and implementation of various economic policies in terms of fiscal and monetary policies is the motivation behind this study. The objective of the study is to examine how effective economic policies have been in terms of fiscal and monetary policies in curbing unemployment and poverty incidence. The variables used are Poverty index (POV), Unemployment Rate (UMP), fiscal policy instruments in terms of Government expenditure (GEX), Tax and Public Debt, Monetary policy instruments in terms of monetary policy rate (MPR), interest rate (INR) and money supply (MS). Time series dynamic analysis was used to analyses the impact of these macroeconomic instruments on poverty and unemployment. The Auto Regressive Distributed Lag (ARDL) Model was used to examine the short-run, interim and long-run effect of economic policies on unemployment and poverty between 1970-2019. Preliminary test such as stationarity test, cointegration test and trend analysis were conducted before estimation. The evidences from various econometrics analyses from this study revealed that, macroeconomic policies such as money supply, government capital expenditure, unemployment rate and interest rate have a statistically significant impact on poverty level in Nigeria from 1970-2019. The implication of this is that an increase in money supply and government expenditure has a negative effect on poverty level but an increase in unemployment rate and inflation rate will lead to higher poverty level in Nigeria since unemployment rate has a positive and significant impact on poverty level. The recommendations made include; that, since government capital expenditure has a negative impact on poverty level, emphasis should be laid on increasing government capital expenditure especially those meant for development programs and projects to enhance employment which will in turn reduce poverty level in the country.
\end{abstract}

Keywords - Unemployment, poverty and government policies. 


\section{INTRODUCTION}

History shows that high rates of economic growth sustained over a period of time are necessary for poverty reduction, while the distribution of the benefits of growth determines the impact on poverty. The macroeconomic policy framework often sets the parameters for social policies by defining the policy and fiscal space for government action. For two and a half decades starting from the end of the Second World War, Governments of the industrialized countries, through active reflationary macroeconomic management, achieved rapid reconstruction and prosperity underpinned by full employment and low inflation. Governments in developing countries also played a very active role in promoting economic growth and structural change after independence from colonial powers was gained. Developing countries as a group experienced impressive economic growth and structural change within their economies. Industry was the fastest-growing sector, resulting in a rapid rise in industry's share of gross domestic product (GDP) in "virtually all the developing economies" (World Bank, 2004).

Nigeria is the most populous country in Africa with a population of 185 million based on 2016 census and having a nominal GDP of \$315 billion in 2016 (World Economic Outlook, 2016). Its Per capita income is $\$ 1528$ in 2017 and as a result of this it was classified as the largest economy in Africa (WDI, 2017). Despite having the largest economy in Africa and $26^{\text {th }}$ in the world in 2015 unemployment rate have been rising in Nigeria (Oduro and Aryee, 2015). The Nigerian economy has remained largely underdeveloped despite the huge human and natural resources. Poverty level is high, unemployment and inflation rates are also high with many socio-economic challenges. The economy has continued to witness economic recovery which is immediately followed by economic recession and depression (Balami, 2006).

According to Gbosi (2004), the situation in Nigeria is disturbing; the various macroeconomic policies by government have been unable to achieve sustained price stability, reduction in unemployment and sustained growth. The fluctuations in the economy have confirmed the need to manage the economy effectively. The essence of macroeconomic management underlines the rationale of the government as a vital economic agent. However, it appears that government intervention has not been able to cure the ills in the economy. For several decades, economic performance has not been impressive (Nyong, 2018). The continued economic crisis, with the associated problems of high inflationary pressure, high exchange rate, debt overhang, adverse balance of payment and high inflation rates is difficult to explain (Balami, 2006). Consequently, the full potentials of labour-surplus economy have not been fully exploited.

In general terms, macroeconomic policies in developing countries, which Nigeria is one, are designed to stabilize the economy, stimulate growth and reduce poverty. The Nigerian factor and the achievement of these objectives are predicted on the stance of fiscal and monetary policiessumming the aggregate of the economic indices for growth evaluation (Awosika, 2018).

Nigeria has lost decades of developments due to the negative-to-slow growth and has been one of the weakest growing economies in the world on a per capita basis especially for the period 1981-2013. Nigeria also represents one quarter of Africa's population and by implication, one of the most poverty prone indicators include high rate of illiteracy, lack of 
access to safe source of drinking water, declining purchasing power, increasing income disparity, poor housing, high child malnutrition and rising mortality rate among children.

The severities of poverty became more pronounced in the 1980s and 1990s, thus necessitating the formulations of specific programs aimed at poverty reduction. The persistent high level of poverty in Nigeria is traced down to policy error which is largely caused by the failure government to modify and fine tune the received macro-economic doctrine to suite the Nigerian context and complexity (Agenor, 2002). According to Agenor (2002), Macroeconomic policies have been rigorously adopted by the Nigerian government such as exchange rate devaluation, trade policy, monetary and fiscal policy but these policies have not yielded desirable results. In the opinion of Agenor (2002) the IMF conditions for the grant of the 1986 loan to Nigeria and the devaluation of the nairais the major cause of Nigeria economic woes creating inflation, unemployment and poverty.

This study examines the impact of macroeconomic policy on poverty level and unemployment in Nigeria. The macroeconomic policy taken is monetary policy proxied by interest rate and money supply and fiscal policy proxied by government expenditure. The study period covers the period of $1990-2019$ based on the availability of relevant data.

\section{LITERATURE REVIEW}

\subsection{Conceptual Clarifications}

i. Unemployment: According to Balami (2006), unemployment is conceptualised as a situation whereby a worker or workers are involuntarily out of work. This means that workers are willing and able to work but cannot find any work. Unemployment is often defined by the classical economists as the excess supply of labour over the demand for labour which is cause by adjustment in real wage. The Classical or real-wage unemployment occurs when real wages for job are set above the market-clearing level, causing number of job-seekers to exceed the number of vacancies.

Unemployment as defined by International Labour Organization (2009) is a state of joblessness which occurs when people are without jobs and they have actively sought work within the past four weeks. The unemployment is a measure of the prevalence of unemployment and it is calculated as a percentage by dividing the number of unemployed individuals by individuals currently in the labour force.

\section{ii. Definition of Poverty}

According to encyclopedia Aassve, Burgess, Dickson and Propper (2005), poverty is defined as an insufficiency of means relating to human needs. Townsend (1992) defines poverty as lack of material and resources that affect an individual's living condition. In a similar vein, poverty is, the degree of difficulty encountered in making ends meet. Aluko, (2005) defined poverty as a situation where the resources of individuals or families are inadequate to provide a socially acceptable standard of living. The German government in 1992 described poor people as "those who are unable to live a decent life" while defining poverty as "not having enough to eat, a high rate of infant mortality, a low life expectancy, low educational opportunities, poor water, inadequate health care, unfit housing and a lack of active participation in the decision making process. World Bank (2014), defined absolute poverty as a condition of life so degrading as to insult human dignity. 
Poverty depicts poor nutrition, inadequate shelter, and low health standard (World Bank 2014). Poverty can also be measured by drawing poverty line. Poverty line is a value of income or consumption necessary to purchase the minimum standard of nutrition and other necessities of life. Therefore, people are counted poor when their measured standard of living in terms of income or consumption is below the poverty line.

\subsection{Empirical Review}

An appraisal of literature on unemployment, inflation and poverty rate reveals that several scholars and researchers worldwide have attempted to examine the subject matter with scope ranging from country-specific studies to panel. Some of these empirical literature are reviewed in this section.

Khan and Senhadji (2011) examine the issue of the existence of threshold effects in the relationship between inflation, unemployment and poverty, using SVAR econometric techniques that provide procedures for estimation and inference for 140 developed and developing countries covering 1995-2013. They estimate a threshold level of inflation above which inflation and unemployment significantly increases poverty rate at 1-3 percent for developed countries and 11-12 percent for developing countries. The positive and significant relationship between inflation, unemployment and poverty, for inflation rates above the threshold level, is quite robust with respect to the estimation method, perturbations in the location of the threshold level, the exclusion of high-inflation observations, data frequency, and alternative specifications.

Osterling (2007) adopted a consumption based approach to measure poverty in the West Africa using a random effect model. Analyzing panel data using eight West African countries from 2000 through 2012, she found a robust and relatively large positive relationship between inflation and the consumption poverty rate. Powers argues that inflation affects the poor directly through a decline in their real wages owing to the short-run rigidity of nominal wages.

Perberton et al (2013) studied the impact unemployment, poverty and inequality on Gross Domestic Product in developing countries including West African Countries using Population Average estimation technique. They found that regression of the change in poverty on the unanticipated change in GDP produced a small and insignificant coefficient. However, the relationship between the change in unemployment rate and the anticipated change in GDP was significant. The point estimate implies that an anticipated increase in unemployment of one percentage point is associated with a decline in GDP of 0.2 percentage points. According to Lupa (2012), unanticipated inflation reduces the real value of nominal assets and liabilities. It therefore causes real capital losses for nominal creditors and real capital gains for nominal debtors. If the poor are net nominal debtors, these effects benefit them.

Ahmed and Mortaza (2011) postulated that moderate and stable inflation rates promote the development process of a country, and hence economic growth and reduction in poverty. Moderate inflation supplements return to savers, enhances investment, and therefore, accelerates economic growth of the country. They explore the present relationship between inflation, poverty and economic growth in the context of Bangladesh. Using annual data set on real GDP, Poverty rate and CPI for the period of 1980 to 2009, an assessment of empirical evidence has been acquired through the co-integration and error correction models. They also explore what the threshold level of inflation should be for the economy. It is established that there exists a statistically significant long-run negative relationship between inflation, poverty 
rate and economic growth for the country as indicated by a statistically significant long-run negative relationship between CPI, Poverty rate and real GDP. The estimated threshold model suggests 6-percent as the threshold level (i.e., structural break point) of inflation above which inflation adversely affects economic growth and increase poverty incidence.

Quartey (2013) put forward that the aim of the policy of price stability is to provide a stable environment for real sector activities to flourish but the outcome of the policy on real sector activities in Ghana has not been subjected to any empirical investigation. He studied Stagflation and macroeconomic performance in Ghana using time series data. The study finds that economic performance is higher under low inflation era than when inflation is high. The results are robust and show that the revenue maximizing rate of growth for Ghana is 9.14 per cent using quarterly data over the period 1990-2011 with least square multiple regression analysis. It is also deduced from the study that the single digit inflation target set by the central bank ofGhana is not growth maximizing.

Fielding (2013) uses monthly time-series data on the prices of 96 individual products in the 37 states of Nigeria to analyze the factors that drive inflation volatility and poverty incidence with VAR. Among the significant determinants of volatility are average inflation rates, transport and communication infrastructure, consumer access to credit markets and urbanization. Analysis of the data reveals that there is substantial heterogeneity across products in relative importance of these non-monetary factors that drive inflation volatility and poverty incidence. Accordingly, better transport and communication infrastructure, as captured by road length, literacy and linguistic homogeneity, are associated with lower inflation volatility and poverty rate in a state. However, more extensive access to credit facilities is associated with higher inflation volatility, as is urbanization. Since most changes in inflation are unanticipated, these results apply equally to conditional and unconditional poverty incidence.

Oduro and Aryee (2015) examined the role played by unemployment on the making of the Nigerian Gross Domestic Product (GDP) for a period of nine years (2000 - 2008). Using the regression analysis, findings showed that unemployment has an enormous effect (over 65 percent) on the making of the Nigerian GDP and there exist an inverse relationship between the model (unemployment) and the GDP - increase in the model leads to decrease on the GDP and vice versa.

Aluko (2005) assess the determinants of poverty as well the poverty coping strategies among farming households in Nasarawa State, Nigeria. The study employed simple random sampling to select 150 farming households and used Costs of Calorie method and Discriminant Analysis to determine the incidence of poverty as well as its determinants respectively. The incidence of poverty among the sampled households was found to be high and the major determinants of poverty include household size, number of income sources of the household head, number of household members employed outside agriculture and the number of literate adult males and females in the household. The major poverty coping strategies include skipping of meals, reduction in the quantity of meals served and engaging in wage labour. The study recommends that the farming households should be effectively involved in the formulation of strategies for imparting knowledge on family planning to the farming households.

Berthod and Grundler (2013) examined the determinants of the urban unemployment in Nigeria. The variables used include level of unemployment and demand for labour, supply of labour, population, inflation, capacity utilization, gross capital formation and nominal wage 
rate. Using time series secondary data and parsimonious error correction mechanism, the study found that the rising nominal wages and the accelerated growth of population which affected the supply side through a high and rapid increase in labour force relative to the absorptive capacity of the economy appear to be the main determinant of high unemployment in Nigeria.

Gordon (2013) examine poverty situation in Nigeria by employing the data of economic growth and millennium development goals (MDGs) expenditure. The methodology employed was panel data analysis consisting of pooled model, fixed-effects, random-effects and weighted least square. The results revealed that, a unit increase in per capita GDP led to 0.6 percent increase in poverty. Similarly, a unit increase in MDG expenditure resulted in 11.56 units increase in relative poverty in the pooled model. The study concluded that economic growth and MDG spending has not substantially reduced poverty over the sample period.

Although previous arguments and evidence tendto support the view that inflation affects poverty positively, there are counter arguments to this. The World Bank Report on the World Social Situation in 2010, Rethinking Poverty, raises a number of interesting questions: If inflation reduces real wages, then employment should rise, creating more income-earning opportunities for workers(World Bank 2014). Therefore, the employment effect of inflation (creating more jobs because of lower labor costs) can outweigh the real-wage effect (lower income) on poverty. This is likely to be the case, as the inflation (real wage) elasticity of poverty is found to be significantly less than the output (employment) elasticity of poverty. Furthermore, most of the poor are net debtors and inflation reduces the real value of their debt. So this way inflation may have a negative correlation with poverty. Thus, the effect of inflation on poverty is not straightforward.

\subsection{Gap in Literature}

The literature reviewed so far has shown that first, inflation is positively correlated with poverty in many cases, but in some cases either there is no clear relationship between inflation and poverty or the relationship, if at all exists, is statistically not significant. Besides, there are some arguments which even contend that the relationship between inflation and poverty could be negative, as well. Second, inflation erodes the value of cash holdings, reduces real income and hence lowers people's purchasing power. Third, inflation inequality is a significant issue that needs more attention as food price inflation affects the poor more adversely than inflation in general. Although the existing literature allows us to know about the relationship between inflation and poverty, most of the studies pertain to a country or a very specific group of countries in a particular region such as Latin America, or Sub-Saharan Africa. So the general question about the relationship between inflation and poverty is yet to be answered. Hence there is scope for a study on the relationship between poverty and inflation with a large cross-section of countries.

It is also evident to contend that the high rate of unemployment among the well educated graduates is the consequence of institutional failure. The Nigerian government of all levels has failed in its contractual obligation to respect and sustain its social contract and promises with the people. There is a somewhat total collapse of social order, high rate of insecurity of lives and properties and prevalent abject poverty trend among the general rural population depict state failure. Secondly, the poor state of economic growth in the face of the growing population accounts for the worsening and precarious unemployment scenario over the years. 


\subsection{Theoretical Framework}

The Human capital theory of poverty serves as the Theoretical Framework for this study. The Human capital theory can be adequately used to explain the effect of unemployment and inflation rate on poverty.

The Human capital theory laid emphasis in the promotion of the crucial aspect of human capital based on the promotion of human capital efficiency through aggregate investment in public education. The role of the government in the economy therefore takes the centre of the stage. It is contended that government intervention against poverty is needed in a wide variety of economic issues, from tackling involuntary unemployment to promoting human capital accumulation through investment in public education, which can both encourage economic growth via the famous multipliers and tackle poverty through the development of abilities it entails. This is in stark contrast with the classical and neoclassical view that the presence of the government in all spheres of the economy should be limited (Olawunmi and Tajudeen 2018).

In a typical liberal approach (Sargsyan, 2013), the main signs of underdevelopment in a country or region include poor levels of: human capital (health, skills and education), business capital (machinery and buildings), infrastructure (transport, power and sanitation), natural capital (viable land), public institutional capital (rule of law and security) and knowledge capital (technical know-how needed to raise productivity). Although the role played by most of these deep-rooted structural factors was originally explained for developing nations, in many respects similar patterns are transferrable to regions or localities of the UK. For example, this view involves a focus on the provision of capital goods, in the form of education (to increase human capital) and infrastructure (to increase productive capacity) flowing to people experiencing poverty, and an overall development of markets that may be applicable, for example, to the North-South divide in the UK.

Sargsyan approach is innovative in being 'clinical' in designing anti-poverty intervention and needing to adapt to circumstances rather than 'one size fits all'. Economies, like persons, should be seen as complex systems, where failures in one part (e.g. corruption) lead to failure elsewhere (e.g. market systems), and 'diseases' differ (Dickens and Ellwood 2001). Factors to be taken into account include the existence of a poverty trap, the economic policy framework, the fiscal framework and fiscal traps, physical geography, governance patterns and failures, cultural barriers and geopolitics. In this regard, poverty in a given country might be heavily affected by the presence of a very weak institutional environment including corruption, for example, which adversely influences the functioning of markets. In another context the most crucial factor may be geographical isolation, which may impede the import of basic goods and services needed for individuals to attain a certain level of wellbeing. Under this view, the importance of such a wide range of factors at the macro level needs to be weighed in each specific case; only then can a particular, tailor-made policy agenda be designed to combat poverty. Similar arguments can apply in advanced countries at the level of the locality or region.

\section{METHODOLOGY}

\subsection{Research Design}

This Study examines the impact of macroeconomic policy on poverty level in Nigeria. Secondary data will be used, sourced from the Central Bank of Nigeria (CBN) statistical bulletin and National Bureau of Statistic (NBS) publication. The data required arepoverty rate 
(percentage of total population living below 2 USD a day), interest rate, Unemployment rate, Money Supply and Government expenditure. The data will be collected from CBN statistical bulletin 2019 vol. iv. GDP is measured in Naira, Oil Output is measured in barrels, Oil Export and Oil Revenue are also measured in Naira. The study period covers 1990-2019.

The method of data analysis to be used shall be the ordinary least square (OLS) method of estimation. The justification for choosing the OLS method as the estimation technique was due to the desirable properties its estimate possess called the BLUE properties. These properties ensure good inference making and efficient as well as non misleading conclusion and recommendations. The choice to use the OLS was also based on the fact that the OLS is among the best estimation method for the linear econometric model.

The OLS estimation of the specified model shall be done using Econometric Views (EViews). The estimated model is evaluated using diagnostic and summary statistic, such as t-statistics, coefficient of multiple determination $\left(\mathrm{R}^{2}\right)$ adjusted $\mathrm{R}^{2}$, f-statistic, Durbin Watson (d) statistics etc. These set of statistics help us to ascertain the reliability and healthiness of the estimated model.

\subsection{Model Specification}

This section will focus mainly on establishing a model to examine the causes of poverty incidence in Nigeria. The Neo-classical theory of poverty which is the theoretical framework of this study will serve as the background for the model use in this research to examine poverty incidence in Nigeria.

A model based on Neo-classical theory of poverty is adapted from the work of Granville and Mallick, (2006) multiple regression model and restricted to incorporate the effect of macroeconomic variables such as unemployment, money supply, poverty rate and government expenditure in Nigeria.

Conventionally,

$\mathrm{UN}=\mathrm{f}(\mathrm{MS}, \mathrm{GEX}, \mathrm{INR})$

$\mathrm{POV}=\mathrm{f}(\mathrm{MS}, \mathrm{GEX}, \mathrm{UN})$

Where,

POV is poverty rate (percentage of total population living below 2 USD a day)

INR is interest rate

$\mathrm{UN}$ is Unemployment rate

MS is Money Supply

GEX is Government expenditure

Equation 3.1 and 3.2 is expanded to and is given as;

$$
\begin{aligned}
& \mathrm{UN}_{\mathrm{t}}=\alpha_{0}+\alpha_{1} \log \mathrm{MS} \mathrm{S}_{\mathrm{t}}+\alpha_{2} \log \mathrm{GEX}_{\mathrm{t}}+\alpha_{3} \mathrm{INR}_{\mathrm{t}}+\mu_{1 \mathrm{t}} \\
& \mathrm{POV}_{\mathrm{t}}=\beta_{0}+\beta_{1} \log \mathrm{MS}_{\mathrm{t}}+\beta_{2} \log \mathrm{GEX}_{\mathrm{t}}+\beta_{3} \mathrm{UN}_{\mathrm{t}}+\mu_{2 \mathrm{t}}
\end{aligned}
$$


$\alpha_{0^{-}} \alpha_{3}, \beta_{0^{-}} \beta_{3}$ are parameters to be estimated

$\mu_{\mathrm{t}}$ is the error term

Note: $\mu_{\mathrm{t}} \sim \operatorname{IID}\left(0, \sigma_{\mu}{ }^{2}\right)$,

From economic literature and empirical studies it is expected that $\alpha_{1}$ from equation 3.4 should be positive since it is expected that money supply and government expenditure have a positive impact on poverty, most empirical studies have established positive relationship between poverty and money supply and government expenditure (see Empirical Review). Also $\beta_{2}$ should be positive since it is expected that unemployment have a positive impact on poverty.

\subsection{Method of Data Analysis}

\section{Stationarity Test}

To test for stationarity, the unit root method will be used and will take the form of an Autoregressive model process, with each variable regressed on its own lagged value and a deterministic variable. The ADF unit root test will be applied and the model is specified as:

$$
\Delta \mathrm{Y}_{\mathrm{t}}=\beta_{1}+\beta_{2} \mathrm{t}+\delta \mathrm{Y}_{\mathrm{t}-1}+\sum_{\mathrm{i}=1}^{\mathrm{m}} \alpha_{\mathrm{i}} \Delta \mathrm{Y}_{\mathrm{t}-\mathrm{i}}+\varepsilon_{\mathrm{t}}
$$

Where;

Y represents all the variables under consideration.

$\delta$ represents the coefficient of the lagged value of $Y$.

$\Delta$ is the first difference operator.

$\mathrm{Y}_{\mathrm{t}-\mathrm{i}}$ represents the lagged terms included

$\mu_{\mathrm{t}}$ represents pure white noise error term.

The null hypothesis to be tested is such that the variable possess unit root, and as such is nonstationary.

$\mathrm{H}_{0}: \delta=0$ presence of unit root

$\mathrm{H}_{0}: \delta \neq 0$ no unit root

The decision rule will be such that if the absolute ADF statistic is greater than the absolute critical values, the null hypothesis will be rejected.

\section{Cointegration Test}

In the case of non-stationarity of any variable, the Johansen Cointegration test will be carried out. The null hypothesis for the Johansen's cointegration test is such that there is no cointegration equation.

\section{RESULTS AND DISCUSSION}

\subsection{Data Presentation and Interpretation of Results 4.2 Data Presentation}

The result presented in this chapter are based on all test stated in chapter three. All results to be analyzed in this chapter are computed using Stata 13, Shazam and Eviews 9.0 statistical software packages.

\subsection{Descriptive Statistics}


The descriptive statistics as derived through E-Views 9.0 shows the Mean, Median, Maximum, Minimum, Standard Deviation, Skewness, Kurtosis, Jacque-Bera and Probability of each of the variables as presented below:

\section{Table 4.1 Descriptive Statistics}

\begin{tabular}{|l|c|c|c|c|c|}
\hline & UNP & POV & MS & INF & GEX \\
\hline Mean & 13.46552 & 44.05535 & 1869257. & 18.43803 & 556346.4 \\
\hline Median & 13.40000 & 43.15192 & 1462933. & 12.21700 & 527576.0 \\
\hline Maximum & 16.80000 & 54.17946 & 9456480. & 72.72900 & 989389.9 \\
\hline Minimum & 10.20000 & 40.10699 & 52857.03 & 5.413000 & 265379.1 \\
\hline Std. Dev. & 2.208470 & 3.913253 & 2225707. & 17.13339 & 260868.7 \\
\hline Skewness & -0.035509 & 1.245206 & 2.207347 & 2.042217 & 0.278760 \\
\hline Kurtosis & 1.634479 & 3.552754 & 7.464517 & 5.949083 & 1.496535 \\
\hline & & & & & \\
\hline Jarque-Bera & 2.259210 & 7.863461 & 47.63423 & 30.66714 & 3.106909 \\
\hline Probability & 0.323161 & 0.019610 & 0.000000 & 0.000000 & 0.211516 \\
\hline & & & & & \\
\hline Sum & 390.5000 & 1277.605 & 54208439 & 534.7030 & 16134047 \\
\hline Sum Sq. Dev. & 136.5655 & 428.7793 & $1.39 \mathrm{E}+14$ & 8219.488 & $1.91 \mathrm{E}+12$ \\
\hline & & & & & \\
\hline Observations & 29 & 29 & 29 & 29 & 29 \\
\hline
\end{tabular}

\section{Trend Analysis}

Graphically, the trend analyses showed that the variables MFP, INT, GE, SBC, VAT and REER fluctuates at one point or the other during the period under review. This was attributed to the effects of government policy and economic conditions that would have had attendant effects on some of these variables. These are presented graphically in figure 1: 

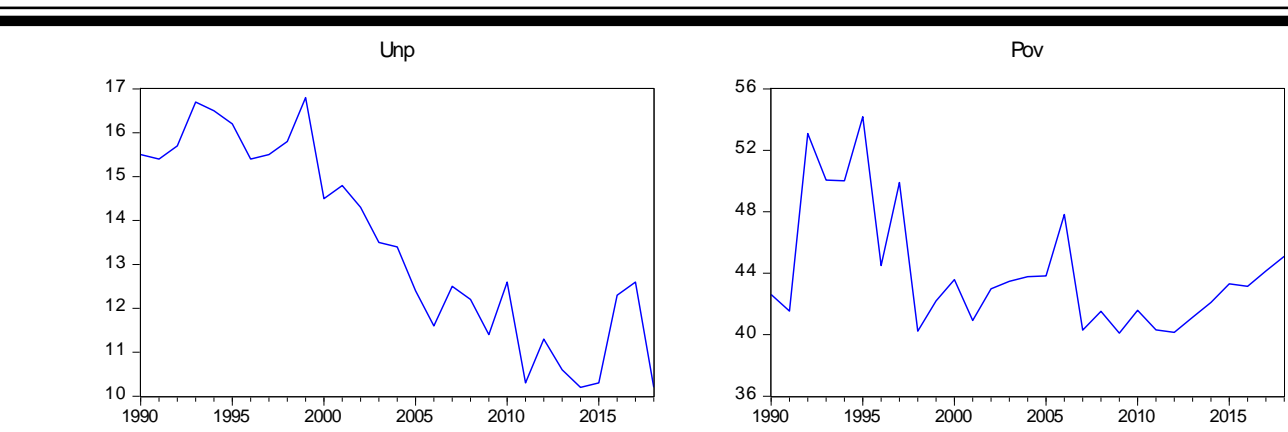

MS

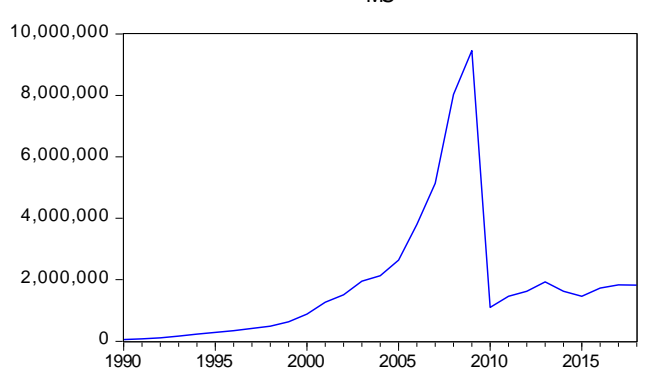

GEX

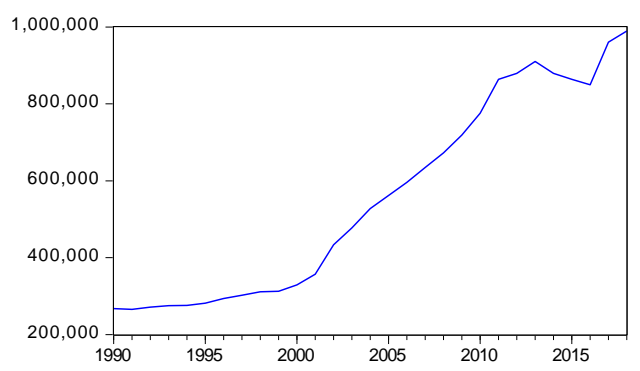

$\operatorname{lnf}$

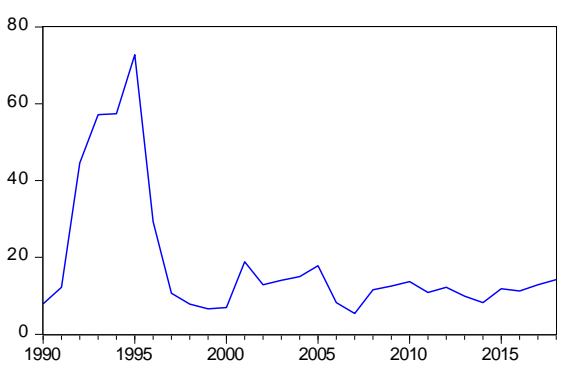

\section{Figure 1.0 Trend Analysis}

\subsection{Data Analysis}

The augmented dickey fuller test is used to test for unit root. All the variables were regressed on trend and intercept to determine if they have trend, it was discovered that POV has only intercept without trend, INR has no intercept and trend and UMP has intercept and trend, hence the unit root test was conducted based on the component of each time series. The result is presented below: 


\subsubsection{Stationarity Result}

\section{Table 4.2: Unit Root Test Result}

\begin{tabular}{|c|c|c|c|}
\hline Time Series & ADF Statistics & Critical Value & Stationary Status \\
\hline POV & -11.03404 & $\begin{array}{l}-3.64634(1 \%) \\
-2.95402(5 \%) \\
-2.61582(10 \%)\end{array}$ & $\mathrm{I}(1)$ \\
\hline INR & -4.783871 & $\begin{array}{l}-2.63690(1 \%) \\
-1.95133(5 \%) \\
-1.61075(10 \%)\end{array}$ & $\mathrm{I}(1)$ \\
\hline UMP & -9.394201 & $\begin{array}{c}-4.2627351 \%) \\
-3.55297(5 \%) \\
-3.20964(10 \%)\end{array}$ & $\mathrm{I}(1)$ \\
\hline GEX & -4.783871 & $\begin{array}{l}-2.63690(1 \%) \\
-1.95133(5 \%) \\
-1.61075(10 \%)\end{array}$ & $\mathrm{I}(1)$ \\
\hline MS & -9.394201 & $\begin{array}{l}-4.2627351 \%) \\
-3.55297(5 \%) \\
-3.20964(10 \%)\end{array}$ & $\mathrm{I}(1)$ \\
\hline
\end{tabular}

The critical values for rejection of hypothesis of unit root were from MacKinnon (1991) as reported in eviews

Source: Author's Computation 2019

The five variables (POV, INR, MS, GEX and UMP) underwent unit root test using the Augmented Dickey-Fuller (ADF) test. As is the case most times, all three variables were found to be non-stationary at levels but were stationary at first difference I(1).

Table 4.3: Johansen's Cointegration Result

\begin{tabular}{|l|c|c|}
\hline \multicolumn{1}{|c|}{ Eigen Value } & Likelihood Ratio & 5 percent Critical Value \\
\hline 0.909231 & $91.81802^{*}$ & 39.89 \\
\hline 0.734959 & $43.82935^{*}$ & 24.31 \\
\hline 0.564966 & $17.27195^{*}$ & 12.53 \\
\hline 0.329342 & $6.039242^{*}$ & 3.94 \\
\hline 0.264134 & $2.271125^{*}$ & 0.23 \\
\hline
\end{tabular}

Source: Author's Computation.

From table 4.3 the all five equations show that the four variables (POV, INR, MS, GEX and UMP) are cointegrated. From the table the likelihood ratios of $(91.81802,43.82935$, $17.27195,6.039242$ and 2.271125) are all greater than their respective critical values $(39.89$, 
$24.31,12.53,3.94$ and 0.23 ) at 5 percent level of significant. This imply that the variables are cointegrated.

\subsection{Interpretation of Results}

Table 4.4 Regression Result model 1

Dependent Variable: $\mathrm{d}(\mathrm{UN})$

\begin{tabular}{|c|c|c|c|c|}
\hline $\begin{array}{l}\text { Independent } \\
\text { Variables }\end{array}$ & Coefficient & Standard Error & t-Statistic & P-Value \\
\hline Constant Intercept & 11.11211 & 5.854008 & 2.759251 & 0.0156 \\
\hline $\mathrm{d}(\mathrm{INR})$ & 0.119821 & 0.026519 & 6.112234 & 0.0000 \\
\hline $\log ((\mathrm{d}) \mathrm{MS})$ & -1.283921 & 0.387739 & -3.188371 & 0.0048 \\
\hline $\log ((d) G E X)$ & -1.342133 & 0.309831 & -5.298311 & 0.0000 \\
\hline $\operatorname{ECM}\left(\mathrm{U}_{\mathrm{t}-1}\right)$ & -0.202570 & 0.040837 & -5.183703 & 0.0000 \\
\hline $\mathrm{R}^{2}$ & 0.511710 & F Statistic & 11.12121 & $\operatorname{Pr}(0.0000)$ \\
\hline Adjusted $\mathrm{R}^{2}$ & 0.501112 & D-W Statistic & 2.104229 & \\
\hline
\end{tabular}

Source: Author's Computation 2019

From the result in table 4.4 the following interpretation can be inferred;

A unit increase in Interest rate on the average holding other independent variables constant will lead to 0.119821 unit increase in POV. This shows that interest rate has a positive impact on Poverty level. This result fulfilsapriori expectation. In addition to this the parameter is significant as indicated by the probability value of the $t$ statistics given as 0.0000 which is less than 0.05 ( $5 \%$ level of significance).

In the same vein, a unit increase in Money supply on the average holding other variables constant will lead to 1.283921 unit decrease in POV. This shows that money supply has a negative impact on poverty level in Nigeria. This result fulfilsapriori expectation. In addition to this the parameter is significant as indicated by the probability value of the $t$ statistics given as 0.0048 which is less than 0.05 (5\% level of significance).

A unit increase in Government expenditure on the average holding other variables constant will lead to 1.342133 unit decrease in POV. This shows that government expenditure has anegativeimpact on poverty level in Nigeria. In addition to this the parameter is significant as indicated by the probability value of the $t$ statistics given as 0.0000 which is less than 0.05 (5\% level of significance).

The Error Correction Mechanism (ECM) measures the speed of adjustment of short-run disequilibrium. The ECM parameter is negative (-) and significant which is -0.202570 , this shows that 20 percent disequilibrium in the previous period is being corrected to restore equilibrium in the current period. 
On the basis of the evaluation criteria chosen in chapter three, the following was obtained after the regression;

The $R$-Squared show that the model is a good fit with $0.511710(51 \%)$ change in POV accounted for by change in the independent variables. This implies that 51 percent of the change in POV was explained by changes in the independent variables.

The Adjusted $R^{2}$ is given as 0.501112 (50 percent). This means that precisely 50 percent of the variations in poverty level in Nigeria are accounted for by the included variables, after the co-efficient of determination $\left(\mathrm{R}^{2}\right)$ has been adjusted to make it insensitive to the number of included variables.

The F statistics which measures the overall significance of the model is 11.12121 and is significant is indicated by the probability value of 0.00000 which is less than 0.05 (5\% level of significance).

Table 4.5 Regression Result Model 2

Dependent Variable: $d(\mathrm{POV})$

\begin{tabular}{|c|c|c|c|c|}
\hline $\begin{array}{l}\text { Independent } \\
\text { Variables }\end{array}$ & Coefficient & Standard Error & t-Statistic & P-Value \\
\hline Constant Intercept & 12.19018 & 5.898632 & 2.798875 & 0.0216 \\
\hline $\log ((\mathrm{d}) \mathrm{MS})$ & -0.122311 & 0.039887 & -5.293872 & 0.0000 \\
\hline $\mathrm{d}(\mathrm{UMP})$ & 1.276519 & 0.365321 & 3.189871 & 0.0083 \\
\hline $\log ((d) G E X)$ & -0.398761 & 0.030998 & -5.209321 & 0.0000 \\
\hline $\operatorname{ECM}\left(\mathrm{U}_{\mathrm{t}-1}\right)$ & -0.200986 & 0.058761 & -5.298311 & 0.0000 \\
\hline $\mathrm{R}^{2}$ & 0.572757 & F Statistic & 15.13937 & $\operatorname{Pr}(0.0000)$ \\
\hline Adjusted $\mathrm{R}^{2}$ & 0.550766 & D-W Statistic & 1.804322 & \\
\hline
\end{tabular}

Source: Author's Computation 2019

\subsection{Interpretation of Results}

From the result in table 4.5 the following interpretation can be inferred;

A unit increase in Money supply on the average holding other independent variables constant will lead to 0.122311 unit decrease in POV. This shows that inflation rate has a negative impact on Poverty level. This result fulfilsapriori expectation and is consistent with other results on money supply and poverty in Nigeria. In addition to this the parameter is significant as indicated by the probability value of the $t$ statistics given as 0.0000 which is less than 0.05 ( $5 \%$ level of significance).

In the same vein, a unit increase in UMP (unemployment rate) on the average holding other variables constant will lead to 1.276519 unit increase in POV. This shows that unemployment rate has a positive impact on poverty level in Nigeria. This result fulfilsapriori expectation 
and is consistent with other results on unemployment and poverty in Nigeria e.gMuhammad, et al., (2011), Bakare (2010). The parameter is significant as indicated by the probability value of the $t$ statistics given as 0.0083 which is less than 0.05 (5\% level of significance).

A unit increase in government expenditure on the average holding other variables constant will lead to 0.398761 unit decrease in POV. This shows that government expenditure has a negative impact on poverty level in Nigeria. In addition to this the parameter is significant as indicated by the probability value of the $t$ statistics given as 0.0000 which is less than 0.05 (5\% level of significance).

The ECM parameter is negative (-) and significant which is -0.200986 , this shows that 59 percent disequilibrium in the previous period is being corrected to restore equilibrium in the current period.

On the basis of the evaluation criteria chosen in chapter three, the following was obtained after the regression;

The $R$-Squared show that the model is a good fit with 0.572757 (57\%) change in POV accounted for by change in the independent variables. This implies that 57 percent of the change in POV was explained by changes in the independent variables.

The Adjusted $R^{2}$ is given as 0.550766 (55 per cent). This means that precisely 96 percent of the variations in poverty level in Nigeria are accounted for by the included variables, after the co-efficient of determination $\left(\mathrm{R}^{2}\right)$ has been adjusted to make it insensitive to the number of included variables.

The F statistics which measures the overall significance of the model is 15.13937 and is significant is indicated by the probability value of 0.00000 which is less than 0.05 (5\% level of significance).

\subsection{Discussion of Results}

From the result interpreted and the findings, unemployment rate cause poverty in Nigeria. This result is in line with the work of Fielding (2013) who carried out the same research on Nigeria, using VAR model and he concluded that unemployment affects poverty incidence in Nigeria. Quartey(2013), Lupa (2012), and Ibrahim and Umar, (2008) all arrived at the same conclusion from their findings. Also money supply and government expenditurereduces poverty incidence in Nigeria, this result is in line with Khan and Senhadji, (2011). Other research such as Sargsyan, (2013) and Reinstadler and Ray (2010) found out that government expenditure and money supply have a significant impact on poverty incidence in Nigeria.

Furthermore, from the poverty incidence is causes by unemployment rate. This result is in line with some studies such as Berthod and Grundler (2013), Ahmed and Mortaza, (2011) who all concluded that poverty is as a result of chronic unemployment. Finally interest rate causes unemployment rate in Nigeria. There is a significant relationship between interestrate and unemployment, indicate that interest rate pass through to unemployment in Nigeria. This result supports that of Kyzyma (2013).

\section{CONCLUSION AND RECOMMENDATIONS}

\section{Conclusion}

The evidences from various econometrics analyses from this study revealed that, macroeconomic policies such as money supply, government capital expenditure, unemployment rate and interest rate have a statistically significant impact on poverty level in 
Nigeria from 1990-2018. The implication of this is that an increase in money supply and government expenditure have a negative effect on poverty level but an increase in unemployment rate and inflation rate will lead to higher poverty level in Nigeria since unemployment rate has a positive and significant impact on poverty level. The finding of this study shows that poverty is eminent in Nigeria and requires a pragmatic approach to minimize it. Increasing the employment rate is not only the way out of this trap but making sure that the most vulnerable group of the economy is taken care of which would then enhance economic growth and development.It is very axiomatic to state that in contemporary times most developed countries of the world have been able to achieve remarkable feat especially in the areas of high rate of employment opportunities, social security and high standard of living. This is not only because they are able to have citizens gainfully employed by their governments. But as a result of imbibing in their citizens the culture and habit of making use of available resources in their areas to get themselves duly employed and not bound to the shackles of poverty.

However, following the summary from this study, it is suggested that further studies on this subject matter need to be taken into consideration, the use of simultaneous equation framework which is capable of explaining better the interdependent relationships and possibility of reverse causation among poverty, inflation and unemployment in Nigeria can be adopted for further research.

\section{Recommendations}

From the conclusion, the following recommendations are made;

i. Since government capital expenditure has a negative impact on poverty level, emphasis should be laid on increasing government capital expenditure especially those meant for development programs and projects. This will reduce poverty level in the country.

ii. Having established a positive and significant relationship between inflation and unemployment, the government should strive to increase supply by increasing domestic production which will bring down price level and increase welfare. A strict macroeconomic policy such as contractionary fiscal and monetary policy should be pursued to curb inflation and reduce unemployment level in Nigeria.

iii. Since money supply has a negative impact on poverty government should adopt expansionary fiscal and monetary policy to increase money supply into the economy so as to reduce poverty rate.

iv. Interest rate hasa significant effect on unemployment, as such interest rate should be lowered to increase investment, productivity and reduce unemployment.

v. Finally having established a positive relationship between unemployment rate and poverty, employment generation scheme should be organized to reduce unemployment in the country. 


\section{REFERENCES}

Aassve, A. Burgess, S. Dickson, M. and Propper, C. ( 2005). Modelling Poverty by not Modelling Poverty: An Application of a Simultaneous Hazards Approach to the UK.Publisher Centre for Market and Public Organisation 05/134, Department of Economics, University of Bristol, UK.

Agenor, P. R. (2002). "Macroeconomic Adjustment and the Poor: Analytical Issues and CrossCountry Evidence", World Bank Working Paper No.: 2788, World Bank: Washington, DC.

Ahmed S. and G. Mortaza (2011). "Inflation and Economic Growth in Bangladesh: 1981-2005.

$$
\text { Department, Bank }
$$

of

Bangladesh.http://siteresources.worldbank.org/PSGLP/Resources/wp0604.pdf.

Aluko, I.R. (2005). Reducing Unemployment through the Informal Sector: A Case Study of Nigeria.European Journal of Economics, Finance and Administrative Sciences ISSN 14502275 Issue 11.

Awosika, A. (2018). Public expenditure and economic growth in Nigeria 1960 to 1992: Final Report. Nairobi: AERC.

Balami, J.E. (2006). "Unemployment statistics and what they mean". Monthly Labour Bulletin, Washington DC; US Department of Labour.

Berthod, N. and Grundler, K. (2013).The Determinants of Stagflation in a Panel of Countries.Journal for social science, Volume 12 (112-141)

Fielding, P. (2013). Price Stability and the Growth Maximizing Rate of Inflation for Ghana, Modern Economy, No. 1, 180-194.

Gbosi, A.N. (2004). Contemporary Macroeconomic Problems and Stabilization Policies in Nigeria, Antovic Ventures, Port Harcourt.

Gordon D. (2013). The concept and measurement of poverty in eds C Pantazis, D Gordon and R Levitas, "Poverty and social exclusion in Britain", Policy Press.

International Labour Organization (2009).African Development Indicators 2009, the World Bank, Washington, D. C.

Khan, M. S. and A. S. Senhadji (2011).Threshold Effects in the Relationship between Inflation and Growth, IMF Staff Papers, Vol. 48, No. 1.

Kyzyma, I. (2013). Changes in the patterns of poverty in Germany, 1992-2009, CEPS-Insead Working Paper No 2013-06.

Lupa, D. V. (2012). The Correlation between Inflation and economic Growth in Romania.LucrăriŞtiinţifice- Vol. 53, SeriaZootehnie.

Mallik, G. and A. Chowdhury (2001).Inflation and Economic Growth: Evidence from South Asian Countries" Asian Pacific Development Journal Vol. 8. No.1. pp 123-135.

Nyong, M. (2018). Dynamics of monetary policy and poverty in a small open economy: The Nigerian experience, Nigerian Journal Economics andDevelopment Matters, 2(4) (2003), 40-68.

Oduro, A.D. and Aryee, I. (2015). "Investigating Chronic Poverty in West Africa" CPRC Working Paper No 28. 
Osterling, K. (2007). Social Capital and neighbourhood poverty: toward an ecologically-grounded model of neighbourhood effects, Journal of Social Behaviour in the Social Environment, Volume 16, Issue 1-2.

Olawunmi, T.O. and Tajudeen (2018).Monetary policies of the federal government strategies since 1986, Central Bank of Nigeria, Economic and Financial Review, 31(4) (1993), 340-350.

Pemberton, S., Sutton, E., Fahmy, E. (2013).A review of the qualitative evidence relating to the experience of poverty and exclusion, PSE-UK Working Paper Methods Series No. 22.

Phillips, A.W. (1958). The Relationship between Unemployment and Rate of Change in Money Wage Rates in the United Kingdom.Economica 25, November.

Quartey, Y. A. (2013). Inflation and Growth: An Estimate of the Threshold Level of Inflation in Ghana, State Bank of Ghana - Research Bulletin, Vol.1, No. 1-2, pp. 35-44.

Reinstadler, A. and Ray J. (2010).Macro determinants of individual income poverty in 93 regions of Europe, CEPS-INSTEAD Working Paper No 2010-13.

Sargsyan, G. R. (2013). Inflation and output in Armenia: The Threshold Effect Revisited, Central Bank of Armenia. http://www.aiprg.net/UserFiles/File/jan-2005/grigorsargsyan.pdf.

Townsend, F. G. (1992), Unemployment, Growth and Taxation in Industrial Countries, Economic Policy 15.

World Bank (2014).Poverty indices in sub-Saharan Africa 2013/2014, the World Bank, Washington, D. C. 